\title{
Management of Electrification at Bouaké University Hospital
}

\author{
Kouadio KS, Koffi N'guessan R*, Ogondon B, Nda Koffi C , Irié Bi GS, Pete Y, Kouamé KE, Boua N and Brouh Y \\ Service Anesthésie Réanimation CHU Bouaké, Côte d'Ivoire
}

Submission: February 22, 2019; Published: March 06, 2019

*Corresponding author: Koffi N'Guessan, Maitre - Assistant, Enseignant chercheur à l'Université Alassane Ouattara (Côte d'Ivoire); service d'Anesthésie - Réanimation au Centre Hospitalier Universitaire (CHU) de Bouaké (Côte d'Ivoire)

\section{Introduction}

The electric current has become an indispensable tool for everyday life. In parallel with the development of its domestic and industrial use, electric accidents have multiplied [1], although they remain relatively rare. In Europe they account for 2.7 to $6 \%$ of the causes of burns [2]. In the United States, about 5,000 people are admitted each year to emergencies following electrification including 1000 deaths [3]. In Côte d'Ivoire, electrical accidents are poorly documented [4]. The aim of our study is to describe the epidemiological, therapeutic and evolutionary aspects of the electrified patients admitted to the intensive care unit of the Bouaké University Hospital.

\section{Materials and Methods}

This was a retrospective and descriptive study. It was carried out over a period of 30 months (from July 2015 to December 2017) in the intensive care unit of the University and Hospital Centre of Bouaké (CHU) (Republic of Côte d'Ivoire). Included were all patients, age and gender combined, who were electrically admitted to the resuscitation department. Data collection was based on patient records. The parameters studied were epidemiological (age, sex, occupation, circumstances of occurrence), clinical (admission delay, type of current, the existence of an entry and exit gate, type of lesion, site of lesions and clinical signs), paraclinical (blood ionogram, blood count, urinary assessment, electrocardiogram and imaging according to the lesions that appeared), therapeutic (symptomatic and / or surgical treatment) and evolutionary order (complications and outcome of the patient: death or favorable evolution). The results were expressed on average for the quantitative variables and as a percentage for the qualitative variables.

\section{Results}

We counted 10 cases of electrification on 1914 patients admitted to the intensive care unit during the study period, a prevalence of $0.52 \%$. The average age was 22 (range, 6 to 50 years). The majority of patients were men (sex ratio H / F 3/1). We registered a bricklayer, two housewives, an electrician, a jobless, three students, a retiree and a radiology technician. The electrisations occurred during an accident at work (2 patients), a domestic accident ( 7 patients) and a gambling accident (1 patient). The average admission time was 4 hours (range 1 hour and 10 hours). Eight patients had burns at the point of contact. For two patients it was a direct contact burn to a high voltage electrical source, while for the other eight it was a low voltage electric current. The average burned skin area was $6 \%$ (range $2 \%$ to $26 \%$ ). The hand was the entryway found in eight patients (Figure 1) while the exit was found in only three patients (foot). Six patients presented first degree burns, only one patient had second degree burns and two patients had third degree burns. We recorded two tables of compartment syndrome and a bilateral fracture chart of both femoral necks after projection. Urines were dark and oliguric for both patients. The rest of the clinical examination was strictly normal for all patients. No patient had an electrocardiogram disorder. A discreet rhabdomyolysis was noted for two patients. No other biological disorder has been recorded. Management consisted of local burn care associated with saline-based vascular filling. The two patients with a syndrome of the lodges benefited from a fasciotomy for one on D1 and for the second on D3. The average length of stay was 2.5 days (range 1 to 9 days). The evolution was encouraging for 7 patients without sequelae. Both patients who presented with a loggia syndrome developed ischemia of the extremities. The evolution was favourable after amputation for a patient, so he was transferred to the trauma department on day 9 of hospitalization. The second patient who refused amputation died in a septic shock chart (Figure 2).

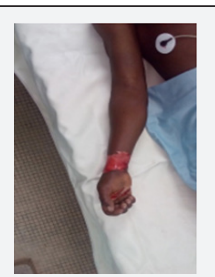

Figure 1: Patient with wrist burn (entrance door to level of the hand). 


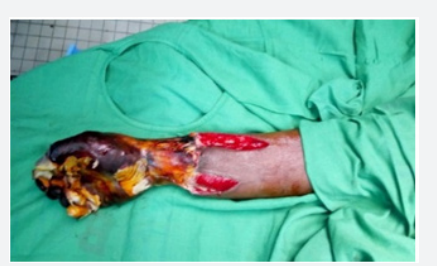

Figure 2: Patient with an appearance of gangrene tissue after fasciotomy.

\section{Discussion}

Electrizations are rare but potentially serious accidents $[4,5]$. We were interested in true electrizations due to the passage of current through the human body between an entry point and an exit point. We found a prevalence of $0.52 \%$, lower than that reported in the literature. This low prevalence can be explained by the number of minor electrizations that did not require consultation or were treated in non-specialized centres. On the other hand, the percentage of burns of electrical origin was similar to that found by Assi in Abidjan [3] and by Moussaoui in Rabat [6]. The number of electrical burns remains generally constant over the years despite the development of safety measures. With regard to the circumstances of occurrence, domestic accidents were the most electrifying. These accidents can be related to faulty installations, lack of insulation of power outlets for children, handling of objects plugged in under the shower or wet hands, handling circuit breakers or uncontrolled connections. These lesions appear in the first hours after electrification. In the case of exposure to a low-voltage current, electrocardiographic monitoring has been rigorous in order to prevent any lesion from going unnoticed [2,7]. The gravity of the electrizations is linked with the evolutionary character of lesions. Thus, two patients developed a syndrome of the lodges then a gangrene indicating an amputation. In 25 to $71 \%$ of cases the use of amputation is inevitable with a major infectious risk that can be life-threatening [1]. Due to the severity of the lesions, the 2 patients with deep burns had a longer hospital stay. The electrizations are associated with a significant mortality between 3 and $15 \%[1,2]$. In the long term the risks are multiple (neurological, ocular, cardiac etc.) hence the importance of monitoring patients at a distance from the accident, even without any initial symptomatology.

\section{Conclusion}

The morbidity related to electrisation remains high despite the efforts made in terms of care. In our context, the focus should be on prevention, especially the houses, where anarchic connections are increasingly used and for exposed professions where safety measures are not always respected.

\section{References}

1. Gueugniaud PY, Vaudelin G, Bertin Maghit M, Petit P (1997) Electrification accidents. In: SFAR, editor. Refresh conferences. 38th National Congress of Anesthesia and Resuscitation. Elsevier, Paris, pp. 479-497.

1. Chaib Draa, Medjellekh M S, Bentakouk M (2009) Electrification. Ann burns fire disasters 22(1): 22-32.

2. Dumler Czuczman A, Zane RD, MA Cooper, Daley BJ (2009) Electrical Injuries: A Review for The Emergency Clinician. EB medicine 11(10): $1-24$.

3. Assi dje bi dje V, Koné SGN J, Ouattara (2014) Electrisations: about 35 cases. Rev int Sc med 16 (1): 17-20.

4. Aurengo H, Bargees L, Folliot D (2005) Accidents of electrization: conditions of the traumatism and physiopathology of the damages. Burns 6(1): 18.

5. Moussaoui A, Fejjal N, Achbouk N, Tourabi K, Ribag Y, et al. (2008) The surgical attitude in serious electric burns by high voltage : about two cases. Ann Burns Fire Disasters 21(2): 90-93.

6. Koumbourlis AC (2002) Electrical injuries. Crit Care Med 30(11): 424430 .

\section{Your next submission with Juniper Publishers} will reach you the below assets

- Quality Editorial service

- Swift Peer Review

- Reprints availability

- E-prints Service

- Manuscript Podcast for convenient understanding

- Global attainment for your research

- Manuscript accessibility in different formats

( Pdf, E-pub, Full Text, Audio)

- Unceasing customer service

\section{Track the below URL for one-step submission}

https://juniperpublishers.com/online-submission.php 